\title{
Training Pedagogical Skills: Evaluation of Lecturers and Teacher Training Students at Educational Universities in Vietnam
}

\author{
Huong Thi Lan $\mathrm{Ha}^{1 *}$, Anh Thi Kim Pham ${ }^{1}$, Ha Thu Nguyen ${ }^{1}$, Ha Thi Thuy Duong ${ }^{1}$ \\ ${ }^{1}$ Institute for Educational Research, Hanoi National University of Education, VIETNAM
}

Received 8 October 2021 - Accepted 15 November 2021

\begin{abstract}
The most critical requirement in Vietnam is improving the quality of training teachers by developing professional skills to meet the requirements of the national innovation in education. This study aims to investigate lecturers' and pre-service teachers' evaluation of the process of teaching pedagogical skills in educational institutions in Vietnam. This is a cross-sectional schoolbased study using the survey to collect data from 448 pre-service teachers and 85 lecturers. The questionnaire was designed based on the research objectives and the standard regulations of the Vietnam Ministry of Education and Training. Cronbach's alpha of the questionnaire was 0.83 . The results of this study are evidence of the inadequacy of learners' needs in pedagogical training programs in teacher training institutions in Vietnam. Educational universities need to improve their training plans, contents, and curriculum to maximize professional skills practice, facilitate soft skills development, and support interaction between lecturers and pre-service teachers. Enhancing professional skills for lecturers and monitoring their teaching process is also recommended.
\end{abstract}

Keywords: evaluation, pedagogical skills, training teachers, Vietnam

\section{INTRODUCTION}

In recent years, the most critical requirement in improving the quality of a school is improving the quality of training teachers (Guerriero, 2014). Teacher quality is essential to enhance students' outcomes (Clotfelter et al., 2010; Das et al., 2007). For example, studies in literacy conducted by Phillips et al. (2001) showed a substantial effect size of 0.48 and 0.89 which referred that after one year, the quality of teachers improved the ability of writing and reading among students. These one-year achievements equaled more than two years' progress. A study also proved that teachers' professional capacity improved $20 \%$ of lowestachieving students (English \& Bareta, 2005).

One of the most critical questions about the quality of training teachers is the pedagogical knowledge and skills among pre-service teachers when they graduate (Texler, 2018). Significant literature has discussed the role of theory and practice in teacher education. Pedagogical skills impact teachers' future and educational quality much more than pedagogical knowledge (Thursby, 2018). If a teacher is excellent at professional knowledge but lacks pedagogical skills, it is hard to become a good teacher (Castro et al., 2019). Teachers' quality, effectiveness, and impact in high schools depend on pedagogical skills in training future teachers (Podolsky et al., 2019). In other words, the essential thing is that educational universities have to find efficient solutions to develop pedagogical skills for pre-service teachers (Negassa \& Engdasew, 2017). Theories in education and practice in teacher training also suggest that the quality of teacher training programs depends on lecturers. Only if lecturers assist pre-service teachers in identifying the gap between teaching and theory and connecting their learned theory and practice can the quality of teacher training programs be improved (Cheng et al., 2010). Korthagen et al. (2006) developed a theoretical framework for changing teacher training with the focus on: (1) Learning about teaching necessitates a shift from the curriculum to the learner; (2) Learning about teaching requires the focus on working closely with peers; (3) Learning about teaching requires

(c) 2021 by the authors; licensee Modestum. This article is an open access article distributed under the terms and conditions of the Creative Commons Attribution License (http://creativecommons.org/licenses/by/4.0/). 


\section{Contribution to the literature}

- This study provides the information about the process of training teachers in educational institutions of Vietnam.

- Difficulties and challenges in training pre-service teachers in the stage of comprehensive reform of education in Vietnam as well as the disparity between the training programs and the process of implementation among lecturers.

- The result of this study provides evidence of the inadequacy of learners' needs in pedagogical training programs in teacher training institutions in Vietnam.

the close relationships between university, pre-service teachers, and the schools where they will practice teaching; and (4) Learning about teaching requires the lecturers model the teaching program in their practice (Korthagen et al., 2006). Based on this, it is crucial to notice the impact of theory and practice of teaching conducted by the lecturers in the classroom.

Pedagogical skills of pre-service teachers are formed based on multi-factors such as motivation, attitude, management and peers supports, and training style and environment (Hajjar \& Alkhanaize, 2018). However, the most important part is learning and practicing pedagogical skills. These activities include setting goals, self-learning to become a dedicated teacher, understanding and encouraging students, planning classroom and outdoor activities, planning and conducting lessons, and assessing students' performance. These skills are formed at the university via practicing and observation. Finally, fieldwork at schools was the last comprehensive step in developing professional skills for pre-service teachers before becoming a real teacher (Nancy, 2007). Some studies confirm the need for "a range of experiences to which student educators are exposed when they work in classrooms and schools" (Kiggundu, 2007). A study in America showed that one of the vital characteristics of high-quality training teachers is the program with practice curriculum in junior schools. The survey among 15,500 teachers who graduated from university in 10-15 years and 2,300 last-year students at training teacher universities reported that all teachers felt the most valuable part of the training program was the period of pedagogical practicing at secondary or high schools (Darling-Hammond, 2006). In Asia, the role of practicing teaching at fieldwork is also every essential. For example, in Malaysia, more than $50 \%$ of the curriculum's credits are for practicing teaching skills (University of Malaya, 2017). The total time for fieldwork practice is at least four weeks (Nguyen, 2014). Although the curriculum might differ among countries, many studies shared the same truth: the quantity of time for practicing teaching skills was predominant in the overall training program. Nevertheless, a large number of teachers are under-trained. It has been observed that teachers are neither professionally qualified nor committed to their careers in some countries (Singh \& Shakir, 2019).
In the last 40 years, Vietnam has been implementing innovation in all areas. The innovation included the transitioning to market economy in light of the economic reform in 1986. During this period, education has played a vital role in developing the socio-economy (Nguyen et al., 2020). In addition, the rising globalization and the international integration trend require higher quality in education in Vietnam (Vietnam Ministry of Education and Training, 2014). The educational innovation in 2000, 2006, 2014, and 2018 have proved the significance of improving the quality of education in this country. During this process, training the future teacher becomes a crucial part of the sustainable development of education. There are some characteristics of teacher training in Vietnam. First, only lecturers at teacher training institutions have the right to train teachers. Second, teachers are qualified for the levels of education and the subjects they would like to teach. Third, the content of the training program usually includes three groups of subjects: (1) general subjects for all pre-service teachers such as psychology, civic education, pedagogy, information science, foreign language, and philosophy; (2) professional subjects; (3) pedagogical skills and methodology (Nguyen, 2002). Currently, training teacher programs face challenges due to the higher requirements from society about the quality of teachers. The training teacher program is facing challenges due to the rising social demands for higher-quality teachers. These programs have many shortcomings, especially in developing professional skills that lead future teachers to expected quality.

There were some studies related to teacher training that has been conducted in Vietnam. For example, a study in 2017 investigated the changing views of teachers and teaching in Vietnam. The willingness of the teacher to train students to accommodate and accept change to a modern teaching and learning style was evaluated. A recent study conducted by Nguyen (2020) focused on the formative assessment used in teacher training institutions in Vietnam. However, other aspects related to professional skills were not included in this study. There is evidence that training teachers in Vietnam have changed over the past years. For example, the change in objectives from training skilled teachers in 1986 to training qualified teachers that meet the innovation needs in 2009 and training teachers to meet 
Table 1. Characteristic descriptions of participants

\begin{tabular}{|c|c|c|c|c|}
\hline Content & & & Quantity & Percentage \\
\hline \multirow{7}{*}{$\begin{array}{l}\text { Student teacher } \\
(\mathrm{N}=448)\end{array}$} & \multirow[t]{2}{*}{ Sex } & Male & 236 & 52.7 \\
\hline & & Female & 212 & 47.3 \\
\hline & \multirow[t]{3}{*}{ Location } & The North & 222 & 49.6 \\
\hline & & The Centre & 123 & 27.4 \\
\hline & & The South & 103 & 23.0 \\
\hline & \multirow[t]{2}{*}{ Major } & Social sciences & 246 & 54.9 \\
\hline & & Natural sciences & 202 & 46.1 \\
\hline \multirow{7}{*}{$\begin{array}{l}\text { Lecturer } \\
(\mathrm{N}=85)\end{array}$} & \multirow[t]{2}{*}{ Sex } & Male & 45 & 52.9 \\
\hline & & Female & 40 & 47.1 \\
\hline & \multirow[t]{2}{*}{ Educational level } & Master & 39 & 45.9 \\
\hline & & $\mathrm{PhD}$ & 46 & 54.1 \\
\hline & \multirow[t]{3}{*}{ Location } & The North & 28 & 32.9 \\
\hline & & The Centre & 30 & 35.3 \\
\hline & & The South & 27 & 31.8 \\
\hline
\end{tabular}

the needs of the 4.0 technology revolution era in 2018 . Nonetheless, the evaluation of pre-service teachers and comparison with the self-report of lecturers related to the professional skill training program has not been considered. This issue is important because the program might meet the requirements of society. Still, the implication of this program among lecturers might not meet the pre-service teachers' needs and expectations. Therefore, the training outcomes might not satisfy either the learners or the society. This study, therefore, aims to investigate lecturers' and pre-service teachers' evaluation of the process of teaching pedagogical skills in educational institutions in Vietnam before discussing some suggestions to improve the present scenario. In other words, the study aims to answer the following questions: (1) How did the pre-service teachers evaluate the effectiveness of the professional skills training curriculum?; (2) How were pre-service teachers' evaluation different from the evaluation of lecturers about the degree of professional skills' contents that the lecturers provided?; (3) How was pre-service teachers' evaluation different from the evaluation of lecturers about implementing the training process?; (4) What were the difficulties of pre-service teachers in learning professional skills and internship?

\section{MATERIALS AND METHODS}

This is a school-based cross-sectional study conducted on pre-service teachers and lecturers at educational universities. Three random cities and provinces were selected representing three main areas in Vietnam: The North, the South, and The Centre. In each location, four random universities of education were selected. A random sample of pre-service teachers and lecturers was recruited and invited to participate in the study. Before collecting the data, the study's aims, participants' rights, and confidentiality were explained clearly to all participants. Consent forms were obtained by signing to the first page of the questionnaire before answering it.
The questionnaire was developed based on the research objectives and the standard regulations of the Vietnam Ministry of Education and Training on training teachers' goals, content, teaching methods, assessment methods, and expected outcomes. This questionnaire focused on the following components: (1) the evaluation of pre-service teachers about the effectiveness of the training curriculum, (2) the lecturers' implementation about teaching pedagogical skills, (3) the lecturers' implementation of the teaching process, (4) the evaluation of pre-service teachers about the professional training skills in general, and (5) the difficulties of preservice teachers in learning pedagogical skills. Each component was identified by using a list of related items. Each item follows the 5-Likert design, in which one is hardly developed or barely used, and five is developed the most or used the most. Cronbach's alpha of the questionnaire was 0.83 .

There were 457 questionnaires distributed to preservice teachers and 95 questionnaires to lecturers who volunteered to answer the survey. Five hundred thirtythree responses were returned, of which 448 were from pre-service teachers and 85 from lecturers (response rate of $96,6 \%$ ). The characteristic descriptions of participants are presented in Table 1.

Collected data were analyzed using SPSS 20.0. Used descriptive statistics included (1) Frequencies and percentages; (2) Mean: to calculate the average score achieved by each component; (3) Standard Deviations (SD): to assess the dispersion of scores around the Mean. To compare differences in evaluating the process of training professional skills between lecturers and preservice teachers, an independent sample t-test was used. The chosen significant level was $a=0.05$ with the statistically significant with $\mathrm{p}<0.05$.

\section{RESULTS}

The following part will present the evaluation of preservice teachers and self-assessment of lecturers on 
Table 2. The effectiveness of the professional skill training curriculum under the pre-service teachers' perspective $(\mathrm{N}=448)$

\begin{tabular}{|c|c|c|c|c|c|c|}
\hline \multirow{2}{*}{\multicolumn{2}{|c|}{$\begin{array}{l}\text { No. Target teachers' qualities and capacities } \\
\text { a) Values for students }\end{array}$}} & \multicolumn{5}{|c|}{ Percentage of performance level (\%) } \\
\hline & & 1 & 2 & 3 & 4 & 5 \\
\hline 1 & Love students and tolerate & 2.7 & 4.5 & 19.6 & 39.3 & 33.9 \\
\hline 2 & Believe that all students can learn & 4,0 & 7.4 & 22.3 & 38.8 & 27.5 \\
\hline 3 & Commitment to nurturing the potential of each student & 0.9 & 7.4 & 18.5 & 42.9 & 30.4 \\
\hline 4 & Value diversity & 0.4 & 1.3 & 16.7 & 39.5 & 42.0 \\
\hline 5 & The consciousness of life-long self-study & 0.9 & 2.7 & 11.8 & 43.1 & 41.5 \\
\hline 6 & Persistence, patience & 0.4 & 2.7 & 15.4 & 40.0 & 41.4 \\
\hline 7 & Creativeness & 0.4 & 3.8 & 13.6 & 38.2 & 44.0 \\
\hline 8 & Professional ethics & 0.4 & 1.8 & 7.8 & 35.0 & 54.9 \\
\hline 9 & Professional capacities & 0.7 & 2.0 & 11.2 & 48.2 & 37.9 \\
\hline 10 & Pedagogical capacities & 0.9 & 2.5 & 9.8 & 43.4 & 43.4 \\
\hline \multicolumn{2}{|c|}{ b) Professional values of a teacher } & 1 & 2 & 3 & 4 & 5 \\
\hline 11 & Love nature, hometown and country & 1.8 & 2.7 & 15.0 & 37.5 & 43.1 \\
\hline 12 & Responsibility and dedication to the job & 1.1 & 2.5 & 7.6 & 42.2 & 46.7 \\
\hline 13 & Commitment to educational quality & 0.7 & 2.0 & 14.7 & 39.1 & 43.5 \\
\hline 14 & Love and proud of the job & 0.7 & 0.9 & 11.6 & 36.8 & 50.0 \\
\hline 15 & Honesty and trustworthiness & 0.2 & 1.6 & 10.5 & 33.9 & 53.8 \\
\hline \multicolumn{2}{|c|}{ c) General capacities } & 1 & 2 & 3 & 4 & 5 \\
\hline 1 & The capacity of autonomy and adapt to changes & 2.5 & 1.8 & 30.6 & 46.9 & 18.3 \\
\hline 2 & The capacity to communicate and cooperate & 2.2 & 2.5 & 18.3 & 47.1 & 29.9 \\
\hline 3 & Leadership capacity & 1.3 & 5.4 & 25.0 & 48.9 & 19.4 \\
\hline 4 & Problem-solving and creative capacity & 0.9 & 3.8 & 19.4 & 44.2 & 31.7 \\
\hline 5 & Cultural-social awareness capacity & 0.2 & 3.3 & 16.1 & 47.1 & 33.3 \\
\hline 6 & Critical capacity & 0.4 & 4.7 & 23.4 & 42.2 & 29.2 \\
\hline 7 & Emotional capacity & 0.7 & 2.5 & 22.1 & 42.2 & 32.6 \\
\hline 8 & Capacity to use information technology & 0.2 & 3.8 & 19.2 & 40.4 & 36.4 \\
\hline \multicolumn{2}{|c|}{ d) Pedagogical capacities } & 1 & 2 & 3 & 4 & 5 \\
\hline 1 & Teaching capacity & 1.6 & 2.0 & 17.0 & 44.1 & 35.3 \\
\hline 2 & Educational capacity & 0.9 & 2.5 & 16.5 & 44.2 & 35.9 \\
\hline 3 & Oriented student development capacity & 0.9 & 4.7 & 19.9 & 48.2 & 26.3 \\
\hline 4 & Social engagement capacity & 0.4 & 3.3 & 15.4 & 49.1 & 31.7 \\
\hline 5 & Career development capacity & & 2.9 & 15.4 & 52.9 & 28.8 \\
\hline
\end{tabular}

Note: 1-Hardy developed to 5-Developed the most

teaching pedagogical skills at university, including the effectiveness of the professional skill training curriculum, the lecturers' implementation of teaching contents and process, general evaluation of professional skills training program and difficulties that pre-service teachers had in learning pedagogical skills, and during internships.

\section{The Effectiveness of the Professional Skill Training Curriculum from the Pre-service Teacher's Perspectives}

The teaching content refers to the values of school students and prospective teachers, including teachers' attitudes to school students, general and specific characteristics of a teacher, and teachers' professional capacities.

Teachers' attitudes to students include the love and tolerance of students, the belief in students' ability to learn, the commitment to nurturing the potential of each student, and the understanding of students' diversity. $73.2 \%$ of pre-service teachers reported that they were developed the most in love and tolerance to students (level 3 and 4) in their classes; 66.3\% for creating the belief in learners' ability to learn; $73.3 \%$ for developing the commitment to nurturing learners' potential; and $81.5 \%$ for forming the understanding of diversity in learners. Meanwhile, some pre-service teachers thought these values were not mentioned at all (level 1) or a low level (level 2) in a class by lecturers. The percentage of responses ranged from $1.7 \%$ (valuing diversity) to $11.4 \%$ (believing that all students can learn) (Table 2).

More than $80 \%$ of participants thought that the curriculum could develop their consciousness of lifelong self-study $(84.6 \%)$. Persistence and patience $(81.4 \%)$, creativeness $(82.2 \%)$, professional ethics $(89.9 \%)$, professional capacities $(86.1 \%)$ and pedagogical capacities (87.8\%) (Table 2). Some values that pre-service teachers did not learn (under 1\%) or provided very little by lecturers (from $1.8 \%$ to $3.8 \%$ ) were related to teachers' characteristics.

Regarding the effectiveness of teaching needed professional characteristics of a teacher. The findings revealed that most of the pre-service teachers reported that their lecturers helped them well in developing the love to nature, hometown, and country (80.6\%), responsibility and dedication to the job (88.9\%), commitment to educational quality $(82.6 \%)$, the love and proud of the job $(86.8 \%)$ and the honesty and 
Table 3. Perceived assessment of lecturers and teacher-students about the extent to which the lecturers cover the contents

\begin{tabular}{|c|c|c|c|c|}
\hline No. & Target teachers qualities and capacities & & Mean (SD) & $t$-test \\
\hline \multicolumn{5}{|c|}{ a) Values for students } \\
\hline \multirow[t]{2}{*}{1} & Love students and tolerate & Student teachers & $3.98(0.98)$ & 0.20 \\
\hline & & Lecturers & $3.95(0.89)$ & \\
\hline \multirow[t]{2}{*}{2} & Believe that all students can learn & Student teachers & $3.78(1.05)$ & $-2.72 * *$ \\
\hline & & Lecturers & $4.11(0.67)$ & \\
\hline \multirow[t]{2}{*}{3} & Commitment to nurturing the potential of each student & Student teachers & $3.94(0.93)$ & 0.38 \\
\hline & & Lecturers & $3.91(0.70)$ & \\
\hline \multirow[t]{2}{*}{4} & Value diversity & Student teachers & $4.21(0.80)$ & 1.14 \\
\hline & & Lecturers & $4.11(0.66)$ & \\
\hline \multirow[t]{2}{*}{5} & The consciousness of self-study, life-long self-study & Student teachers & $4.22(0.82)$ & -0.92 \\
\hline & & Lecturers & $4.31(0.67)$ & \\
\hline \multirow[t]{2}{*}{6} & Persistence, patience & Student teachers & $4.19(0.85)$ & 0.75 \\
\hline & & Lecturers & $4.12(0.79)$ & \\
\hline \multirow[t]{2}{*}{7} & Creativeness & Student teachers & $4.21(0.85)$ & 0.97 \\
\hline & & Lecturers & $4.12(0.79)$ & \\
\hline \multirow[t]{2}{*}{8} & Professional ethics & Student teachers & $4.42(0.75)$ & -0.72 \\
\hline & & Lecturers & $4.48(0.59)$ & \\
\hline \multirow[t]{2}{*}{9} & Professional capacities & Student teachers & $4.21(0.77)$ & -1.63 \\
\hline & & Lecturers & $4.35(0.65)$ & \\
\hline \multirow[t]{2}{*}{10} & Pedagogical capacities & Student teachers & $4.26(0.80)$ & $-2.43^{*}$ \\
\hline & & Lecturers & $4.48(0.59)$ & \\
\hline \multicolumn{5}{|c|}{ b) Professional values of a teacher } \\
\hline \multirow[t]{2}{*}{11} & Love nature, hometown, and country & Student teachers & $4.17(0.91)$ & $2.32^{*}$ \\
\hline & & Lecturers & $3.93(0.81)$ & \\
\hline \multirow[t]{2}{*}{12} & Responsibility and dedication to the job & Student teachers & $4.31(0.81)$ & 0.16 \\
\hline & & Lecturers & $4.29(0.67)$ & \\
\hline \multirow[t]{2}{*}{13} & Commitment to educational quality & Student teachers & $4.23(0.82)$ & 0.99 \\
\hline & & Lecturers & $4.13(0.84)$ & \\
\hline \multirow[t]{2}{*}{14} & Love and proud of the job & Student teachers & $4.35(0.77)$ & 0.30 \\
\hline & & Lecturers & $4.32(0.71)$ & \\
\hline \multirow[t]{2}{*}{15} & Honesty and trustworthiness & Student teachers & $4.40(0.76)$ & 1.41 \\
\hline & & Lecturers & $4.27(0.64)$ & \\
\hline
\end{tabular}

Note: SD - Standard Deviation; ${ }^{*} p<0.05 \quad{ }^{* *} p<0.01$ *** $p<0.001$

trustworthiness (87.7\%). However, some pre-service teachers thought that it was at the low level that their lecturers formed for them the love of nature, hometown, and country $(4.5 \%)$, the commitment to educational quality $(3.6 \%)$, the love and pride of the job $(1.6 \%)$, and honesty, and trustworthiness $(1.8 \%)$.

More than half of pre-service teachers agreed that their lecturers developed for them well in general skills. These capacities included the ability of autonomy and adapt to changes $(65.2 \%)$, communication and cooperation skills (77.0\%), leadership 68.3\%), problemsolving and creative skills $(75.9 \%)$, cultural-social awareness capacity $(80.4 \%)$, critical skills (71.4\%), emotional ability (74.8\%), and information technology skills $(76.8 \%)$.

More than two-thirds of the pre-service teachers agreed that pedagogical skills that they benefited the most from the university were teaching abilities (79.4\%) and educational capacity $(80.1 \%)$, student-oriented development skills $(74.5 \%)$, social engagement $(80.8 \%)$, and career development skills (81.7\%) (Table 2).

Among all of the target qualities and capacities taught at university, the value pre-service teachers felt that they learned the most included professional ethics
$($ Mean $=4.42, \mathrm{SD}=0.75)$, followed by honesty and trustworthiness $($ Mean $=4.40, \mathrm{SD}=0.76)$, the love and job pride $($ Mean $=4.35, \mathrm{SD}=0.77)$, responsibility and dedication to the job $($ Mean $=4.31, S D=0.81)$. The value that pre-service teachers did not learn much at university is the capacity of autonomy and adaptiveness to changes (Mean $=3.77, \mathrm{SD}=0.85$ ), followed by the belief that all students can learn (Mean $=3.78, \mathrm{SD}=1.05)$ and leadership skills (Mean $=3.80, \mathrm{SD}=0.86$ ). The teachers' professional values seemed to be high among pre-service teachers with the Mean above four (Table 3).

\section{The Comparison Between Lecturers' Self-evaluation and Pre-service Teachers' Evaluation of the Extent to Which the Lecturers Cover the Contents}

Twenty-eight professional skills that lecturers usually aim to develop for pre-service teachers were investigated in this study. Detailed skills are shown in Table 3.

There were significant differences between lecturers' and pre-service teachers' opinions about the degree to which professional skills' contents were provided. Lecturers thought that they helped pre-service teachers form the belief in the learning capacity of all students at 
Table 3 (continued). Perceived assessment of lecturers and teacher-students about the extent to which the lecturers cover the contents

\begin{tabular}{|c|c|c|c|c|}
\hline \multirow{2}{*}{\multicolumn{5}{|c|}{$\begin{array}{l}\text { No. Target teachers qualities and capacities } \\
\text { c) General capacities }\end{array}$}} \\
\hline & & & & \\
\hline \multirow[t]{2}{*}{16} & The capacity of autonomy and adapt to changes & Student teachers & $3.77(0.85)$ & $-2.21^{*}$ \\
\hline & & Lecturers & $3.99(0.73)$ & \\
\hline \multirow[t]{2}{*}{17} & The capacity to communicate and cooperate & Student teachers & $4.00(0.89)$ & $-3.01^{* *}$ \\
\hline & & Lecturers & $4.31(0.71)$ & \\
\hline \multirow[t]{2}{*}{18} & Leadership capacity & Student teachers & $3.80(0.86)$ & $3.78^{* * *}$ \\
\hline & & Lecturers & $3.41(0.85)$ & \\
\hline \multirow[t]{2}{*}{19} & Problem-solving and creative capacity & Student teachers & $4.02(0.86)$ & -0.29 \\
\hline & & Lecturers & $4.05(0.79)$ & \\
\hline \multirow[t]{2}{*}{20} & Cultural-social awareness capacity & Student teachers & $4.10(0.80)$ & $3.48^{* *}$ \\
\hline & & Lecturers & $3.76(0.84)$ & \\
\hline \multirow[t]{2}{*}{21} & Critical capacity & Student teachers & $3.95(0.87)$ & 0.45 \\
\hline & & Lecturers & $3.91(0.75)$ & \\
\hline \multirow[t]{2}{*}{22} & Emotional capacity & Student teachers & $4.04(0.84)$ & 1.54 \\
\hline & & Lecturers & $3.88(0.76)$ & \\
\hline \multirow[t]{2}{*}{23} & Capacity to use information technology & Student teachers & $4.09(0.85)$ & -1.15 \\
\hline & & Lecturers & $4.20(0.70)$ & \\
\hline \multicolumn{5}{|c|}{ d) Pedagogical capacities } \\
\hline \multirow[t]{2}{*}{24} & Teaching capacity & Student teachers & $4.10(0.86)$ & $-4.69^{* * *}$ \\
\hline & & Lecturers & $4.55(0.57)$ & \\
\hline \multirow[t]{2}{*}{25} & Educational capacity & Student teachers & $4.12(0.83)$ & $-2.08^{*}$ \\
\hline & & Lecturers & $4.29(0.69)$ & \\
\hline \multirow[t]{2}{*}{26} & Oriented student development capacity & Student teachers & $3.95(0.85)$ & $-2.23^{*}$ \\
\hline & & Lecturers & $4.16(0.69)$ & \\
\hline \multirow[t]{2}{*}{27} & Social engagement capacity & Student teachers & $4.08(0.80)$ & $2.49^{*}$ \\
\hline & & Lecturers & $3.85(0.76)$ & \\
\hline \multirow[t]{2}{*}{28} & Career development capacity & Student teachers & $4.07(0.74)$ & -1.18 \\
\hline & & Lecturers & $4.18(0.69)$ & \\
\hline
\end{tabular}

Table 4. Perceived assessment of lecturers $(\mathrm{N}=85)$ and student teachers $(\mathrm{N}=448)$ about the lecturers' implementation of the teaching process in class

\begin{tabular}{lllll}
\hline No. & Components of the teaching process & & Mean (SD) & $t$-test \\
\hline a) Identifying subject's objectives & & $3.92(0.91)$ & $-4.01^{* * *}$ \\
1 & Clear and specific that reflect the general and specific & Student teachers & $4.34(0.68)$ & $-3.37^{* *}$ \\
& objectives. & Lecturers & $4.01(0.85)$ & $4.34(0.68)$ \\
2 & Defining clearly the competencies in the output & Student teachers & $4.00(0.89)$ & $-2.29^{*}$ \\
& standards of the training program & Lecturers & $4.24(0.73)$ & \\
\hline
\end{tabular}

Note: SD - Standard Deviation; ${ }^{*} p<0.05 \quad{ }^{* *} p<0.01 \quad{ }^{* * *} p<0.001$

a higher level than pre-service teachers did $(t=-2.72$, $\mathrm{p}<0.01)$. The following skills were covered in the lecture was also rated higher by lecturers than their pre-service teachers: pedagogical capacities $(t=-2.43, \mathrm{p}<0.05)$, the development of autonomy and adaptation to changes capacities $(\mathrm{t}=-2.21, \mathrm{p}<0.05)$, communication and cooperation skills $(t=-3.01, p<0.01)$, the forming of teaching capacity $(\mathrm{t}=-4.69, \mathrm{p}<0.001)$, educational capacity $(t=-2.08, p<0.05)$, and the ability to orient student's capacity development $(\mathrm{t}=-2.23, \mathrm{p}<0.05)$. However, leadership and cultural-social awareness skills were appraised higher among pre-service teachers than their lecturers $(\mathrm{t}=3.78, \mathrm{p}<0.001$ and $\mathrm{t}=3.48, \mathrm{p}<0.01$, respectively).

\section{The Comparison Between Lecturers' Self-evaluation and Pre-service Teachers' Evaluation of the Teaching Process in Class}

Table 4 shows that lecturers scored higher than teachers training students in different components of the training process, including the subject's objectives, contents, teaching methods, and evaluation process. Regarding the aim of the subject, lecturers' evaluation was higher than pre-service teachers in identifying explicit and specific goals $(\mathrm{t}=-4.01, \mathrm{p}<0.001)$; clearly defining the plans in the output standards $(t=-3.37$, $\mathrm{p}<0.01)$; defining expected vocational competency outcomes $(\mathrm{t}=-2.29, \mathrm{p}<0.05)$. 
Table 4 (continued). Perceived assessment of lecturers $(\mathrm{N}=85)$ and student teachers $(\mathrm{N}=448)$ about the lecturers' implementation of the teaching process in class

\begin{tabular}{|c|c|c|c|c|}
\hline \multirow{2}{*}{\multicolumn{5}{|c|}{$\begin{array}{l}\text { No. Components of the teaching process } \\
\text { b) The subject's contents }\end{array}$}} \\
\hline & & & & \\
\hline \multirow[t]{2}{*}{1} & \multirow{2}{*}{$\begin{array}{l}\text { Towards training objectives and output standards of the } \\
\text { program }\end{array}$} & Student teachers & $4.09(0.85)$ & \multirow[t]{2}{*}{$-2.77^{* *}$} \\
\hline & & Lecturers & $4.36(0.77)$ & \\
\hline \multirow[t]{2}{*}{2} & \multirow{2}{*}{$\begin{array}{l}\text { Towards developing professional capacities and } \\
\text { characteristics for student teacher }\end{array}$} & Student teachers & $4.11(0.76)$ & \multirow[t]{2}{*}{$-2.68^{* *}$} \\
\hline & & Lecturers & $4.35(0.74)$ & \\
\hline \multirow[t]{2}{*}{3} & \multirow{2}{*}{$\begin{array}{l}\text { The content is essential, modern, practical, associated } \\
\text { with the national general education }\end{array}$} & Student teachers & $4.06(0.84)$ & \multirow[t]{2}{*}{$-3.19^{* *}$} \\
\hline & & Lecturers & $4.36(0.71)$ & \\
\hline \multirow[t]{2}{*}{4} & \multirow{2}{*}{$\begin{array}{l}\text { Integrate educating professional values and teacher's } \\
\text { personality qualities }\end{array}$} & Student teachers & $4.08(0.76)$ & \multirow{2}{*}{$-2.81^{* *}$} \\
\hline & & Lecturers & $4.33(0.73)$ & \\
\hline \multirow[t]{2}{*}{5} & \multirow[t]{2}{*}{ Inheriting known knowledge of professional skills } & Student teachers & $4.05(0.77)$ & \multirow[t]{2}{*}{$-2.51^{*}$} \\
\hline & & Lecturers & $4.27(0.64)$ & \\
\hline \multirow[t]{2}{*}{6} & Integrating relevant subjects in the pedagogical skill & Student teachers & $4.02(0.81)$ & -1.17 \\
\hline & training program & Lecturers & $4.13(0.75)$ & \\
\hline 7 & Matching learners' level & Student teachers & $3.95(0.87)$ & $-3.71^{* * *}$ \\
\hline & & Lecturers & $4.32(0.62)$ & \\
\hline 8 & In accordance with the facilities & Student teachers & $3.91(0.90)$ & $-3.03^{* *}$ \\
\hline & & Lecturers & $4.22(0.66)$ & \\
\hline 9 & Suitable and convenient for training & Student teachers & $4.00(0.93)$ & $-2.05^{*}$ \\
\hline & & Lecturers & $4.21(0.66)$ & \\
\hline 10 & Update new requirements in professional training & Student teachers & $4.12(0.88)$ & -1.82 \\
\hline & & Lecturers & $4.31(0.66)$ & \\
\hline 11 & The ratio between theory - practice - self-study is & Student teachers & $3.92(0.91)$ & $-3.96^{* * *}$ \\
\hline & reasonably & Lecturers & $4.33(0.68)$ & \\
\hline 12 & Practical content associated with practice and contents in & Student teachers & $3.97(0.88)$ & $-3.81^{* * *}$ \\
\hline & high school & Lecturers & $4.35(0.59)$ & \\
\hline 13 & Practical content suitable for modern technical science & Student teachers & $3.94(0.90)$ & -0.27 \\
\hline & and technology & Lecturers & $3.96(0.72)$ & \\
\hline 14 & Practice content aims to form scientific attitudes & Student teachers & $4.01(0.83)$ & -0.99 \\
\hline & & Lecturers & $4.11(0.69)$ & \\
\hline 15 & Practice content is associated with forming soft skills & Student teachers & $4.05(0.85)$ & -1.40 \\
\hline & & Lecturers & $4.19(0.66)$ & \\
\hline c) $\mathrm{Te}$ & ching methods & & & \\
\hline 1 & Suitable with the objectives, contents, and characteristics & Student teachers & $3.95(0.89)$ & $-4.74^{\star * *}$ \\
\hline & of the subject & Lecturers & $4.42(0.61)$ & \\
\hline 2 & Suitable for learners' learning characteristics and & Student teachers & $3.89(0.93)$ & $-2.83^{* *}$ \\
\hline & $\begin{array}{l}\text { strategies; promote self-study and research in student } \\
\text { teachers }\end{array}$ & Lecturers & $4.19(0.63)$ & \\
\hline 3 & Positive teaching method according to the orientation of & Student teachers & $4.11(0.88)$ & $-2.70^{* *}$ \\
\hline & capacity development & Lecturers & $4.38(0.62)$ & \\
\hline 4 & Appropriate to develop soft skills for student teachers in & Student teachers & $3.92(0.90)$ & $-2.06^{*}$ \\
\hline & career activities in the future & Lecturers & $4.13(0.69)$ & \\
\hline 5 & Help to develop learning needs and continuous & Student teachers & $4.01(0.84)$ & -1.81 \\
\hline & professional development in student teachers & Lecturers & $4.19(0.72)$ & \\
\hline 6 & Develop skills of organizing learning for student teachers & Student teachers & $3.98(0.87)$ & $-3.44^{* *}$ \\
\hline & & Lecturers & $4.32(0.62)$ & \\
\hline 7 & Teaching through practical experience & Student teachers & $3.93(0.93)$ & $-3.26^{* *}$ \\
\hline & & Lecturers & $4.27(0.68)$ & \\
\hline 8 & Create an academic environment, positive interaction and & Student teachers & $4.01(0.85)$ & $-2.07^{*}$ \\
\hline & $\begin{array}{l}\text { encourage students in developing critical and creative } \\
\text { thinking }\end{array}$ & Lecturers & $4.21(0.73)$ & \\
\hline 9 & Listening actively and support when students have & Student teachers & $4.02(0.96)$ & $-2.10^{*}$ \\
\hline & learning difficulties & Lecturers & $4.25(0.63)$ & \\
\hline 10 & Select and use traditional and modern teaching facilities, & Student teachers & $4.04(0.88)$ & $-3.13^{* *}$ \\
\hline & $\begin{array}{l}\text { equipment, and aids that are suitable for the lesson and } \\
\text { effectively }\end{array}$ & Lecturers & $4.35(0.59)$ & \\
\hline 11 & Use suitable audio-visual media (movies, videos, maps, & Student teachers & $4.22(0.85)$ & 0.22 \\
\hline & slides ...) & Lecturers & $4.20(0.72)$ & \\
\hline 12 & Using the internet to exploit and support classroom & Student teachers & $4.07(0.88)$ & -0.08 \\
\hline & teaching & Lecturers & $4.08(0.78)$ & \\
\hline 13 & Organizing teaching towards efficient exploitation of & Student teachers & $4.09(0.87)$ & 0.73 \\
\hline & library resources and other conditions. & Lecturers & $4.01(0.73)$ & \\
\hline
\end{tabular}

Note: SD - Standard Deviation; ${ }^{*} p<0.05 \quad{ }^{* *} p<0.01 \quad{ }^{* * *} p<0.001$ 
Table 4 (continued). Perceived assessment of lecturers $(\mathrm{N}=85)$ and student teachers $(\mathrm{N}=448)$ about the lecturers' implementation of the teaching process in class

\begin{tabular}{|c|c|c|c|c|}
\hline \multirow{2}{*}{\multicolumn{5}{|c|}{$\begin{array}{l}\text { No. Components of the teaching process } \\
\text { d) Evaluation }\end{array}$}} \\
\hline & & & & \\
\hline \multirow[t]{2}{*}{1} & \multirow{2}{*}{$\begin{array}{l}\text { Develop a bank of test questions according to the } \\
\text { subject's objectives }\end{array}$} & Student teachers & $3.84(0.91)$ & $-2.71^{* *}$ \\
\hline & & Lecturers & $4.13(0.81)$ & \\
\hline \multirow[t]{2}{*}{2} & \multirow{2}{*}{$\begin{array}{l}\text { Compile test and exam question } \\
\text { s aimed at assessing students' performance capacity }\end{array}$} & Student teachers & $3.97(0.93)$ & $-2.37^{*}$ \\
\hline & & Lecturers & $4.22(0.71)$ & \\
\hline \multirow[t]{2}{*}{3} & \multirow{2}{*}{$\begin{array}{l}\text { Design test/exam to evaluate higher-order thinking } \\
\text { capabilities (applying, analyzing, synthesizing...) }\end{array}$} & Student teachers & $4.01(0.89)$ & -1.65 \\
\hline & & Lecturers & $4.18(0.76)$ & \\
\hline \multirow[t]{2}{*}{4} & \multirow{2}{*}{$\begin{array}{l}\text { Test - evaluate the progress and development of } \\
\text { learners }\end{array}$} & Student teachers & $4.00(0.94)$ & $-2.00 *$ \\
\hline & & Lecturers & $4.21(0.74)$ & \\
\hline \multirow[t]{2}{*}{5} & \multirow{2}{*}{$\begin{array}{l}\text { Integrating testing - evaluation into the teaching } \\
\text { process }\end{array}$} & Student teachers & $4.06(0.93)$ & $-2.14^{*}$ \\
\hline & & Lecturers & $4.28(0.68)$ & \\
\hline \multirow[t]{2}{*}{6} & \multirow{2}{*}{$\begin{array}{l}\text { Use diverse and flexible forms, methods, and } \\
\text { assessment tools that suit learning contents }\end{array}$} & Student teachers & $4.02(0.95)$ & -1.79 \\
\hline & & Lecturers & $4.21(0.69)$ & \\
\hline \multirow[t]{2}{*}{7} & \multirow{2}{*}{$\begin{array}{l}\text { Combining regular evaluation with the process and } \\
\text { final evaluation }\end{array}$} & Student teachers & $4.08(0.87)$ & $-3.05^{* *}$ \\
\hline & & Lecturers & $4.39(0.71)$ & \\
\hline \multirow[t]{2}{*}{8} & \multirow{2}{*}{$\begin{array}{l}\text { Evaluate the ability to apply knowledge and skills to } \\
\text { practical situations }\end{array}$} & Student teachers & $4.08(0.86)$ & -0.94 \\
\hline & & Lecturers & $4.18(0.76)$ & \\
\hline \multirow[t]{2}{*}{9} & \multirow{2}{*}{$\begin{array}{l}\text { Conducting multi-dimensional assessment (teacher- } \\
\text { student, student-student and self-assessment) }\end{array}$} & Student teachers & $4.00(0.91)$ & -0.71 \\
\hline & & Lecturers & $4.07(0.78)$ & \\
\hline \multirow[t]{2}{*}{10} & \multirow{2}{*}{$\begin{array}{l}\text { Instruct students how to be assessed during the } \\
\text { course }\end{array}$} & Student teachers & $4.07(0.94)$ & $-2.36^{*}$ \\
\hline & & Lecturers & $4.32(0.66)$ & \\
\hline \multirow[t]{2}{*}{11} & \multirow{2}{*}{$\begin{array}{l}\text { Students know how to self-assessment in the learning } \\
\text { process }\end{array}$} & Student teachers & $4.01(0.89)$ & -0.92 \\
\hline & & Lecturers & $4.11(0.79)$ & \\
\hline \multirow[t]{2}{*}{12} & \multirow{2}{*}{$\begin{array}{l}\text { Provide feedback before and during the evaluation } \\
\text { process }\end{array}$} & Student teachers & $3.99(0.84)$ & $-2.33^{*}$ \\
\hline & & Lecturers & $4.21(0.71)$ & \\
\hline \multirow[t]{2}{*}{13} & \multirow{2}{*}{$\begin{array}{l}\text { Use the results of the assessment to adjust lecturers' } \\
\text { teaching methods }\end{array}$} & Student teachers & $4.00(0.90)$ & $-2.64^{* *}$ \\
\hline & & Lecturers & $4.27(0.70)$ & \\
\hline \multirow[t]{2}{*}{14} & \multirow{2}{*}{$\begin{array}{l}\text { Use the results of the assessment to adjust learners' } \\
\text { learning methods }\end{array}$} & Student teachers & $4.10(0.88)$ & -1.44 \\
\hline & & Lecturers & $4.25(0.65)$ & \\
\hline
\end{tabular}

Regarding training contents, compared to learners' perception, lecturers self-reported higher in providing appropriate subject's contents $(\mathrm{t}=-3.19, \mathrm{p}<0.01)$; meeting the objects and output standards $(t=-2.77, p<0.01)$; building teachers' professional skills and characteristics $(\mathrm{t}=-3.19, \mathrm{p}<0.01)$; integrating teacher's professional skills and qualities $(\mathrm{t}=-2.81, \mathrm{p}<0.01)$, matching learners' level $(t=-3.71, p<0.001)$, suitability for facilities $(t=-3.01$, $\mathrm{p}<0.01$ ) or the reasonability of the ratio between theory and practice $(\mathrm{t}=-3.96, \mathrm{p}<0.001)$.

In terms of teaching methods, lecturers self-reported higher than prospective teachers in the appropriateness of choosing objectives, contents $(t=-4.74, p<0.001)$, and learners' features $(\mathrm{t}=-2.83, \mathrm{p}<0.01)$. Teaching through practical experience and creating a positive learning environment were applied higher by lecturers' evaluation than by pre-service teachers' evaluation $(\mathrm{t}=$ 3.26, $\mathrm{p}<0.01$ ). Lecturers also thought they listened and supported learners much more than their pre-service teachers' thought $(\mathrm{t}=-2.10, \mathrm{p}<0.05)$.

Different aspects of the evaluation process shared the same trend, in which lecturers self-reported higher than pre-service teachers in using some evaluation methods, such as developing test questions banks $(t=-2.71$, $\mathrm{p}<0.01)$, test and exam questions aiming at assessing students' performance $(\mathrm{t}=-2.37, \mathrm{p}<0.01)$, combining regular evaluation and final evaluation $(t=-3.05, p<0.01)$, providing feedback during and after evaluation and adjusting teaching methods after evaluation $(t=-2.33$, $p<0.05$ and $t=-2.64, p<0.01$, respectively). Findings also revealed that the percentage of lecturers who thought that they ultimately did not comply with the requirements of teaching professional skills ranged from $0 \%$ to $1.7 \%$. This rate, according to students' judgment, was from 1.3 to $9.7 \%$.

\section{Pre-service Teachers' Evaluation of Teaching Professional Skills at University}

The overall evaluation of pre-service teachers about the university's professional teaching skills was examined to further comprehend the feeling and satisfaction among pre-service teachers. Data from Table 4 show that the degree to which pre-service teachers agreed with positive components of teaching professional skills at university was above average (< $85 \%)$. The highest appreciation component was that the training program was easy to understand and easy to apply in practice $(82.4 \%)$, followed by being attractive and lively criteria $(79 \%)$ and well-equipped with basic knowledge $(78.8 \%)$. The most underrated criteria were the extra-curriculum practical sessions (17.6\%), active attitude in learning among lecturer-student (22.8\%), 
Table 5. Evaluation of student teachers about teaching professional skills at the university $(\mathrm{N}=448)$

\begin{tabular}{llccc}
\hline \multirow{2}{*}{ No. } & Contents & \multicolumn{3}{c}{ Percentage (\%) } \\
\cline { 3 - 5 } & & Agree & Hesitation & Disagree \\
\hline 1 & Attractive and lively & 79.0 & 14.5 & 1.3 \\
2 & Easy to understand, easy to apply in practice & 82.4 & 10.5 & 7.1 \\
3 & Promote positivity in learners & 66.5 & 12.7 & 20.8 \\
4 & Academic with modern and updated theory & 34.5 & 20.1 & 44.5 \\
5 & Equipped with basic knowledge & 78.8 & 10.7 & 10.5 \\
6 & Many extra-curriculum practical sessions & 17.6 & 47.3 & 35.0 \\
7 & Many contents have been updated with the renovation of general education & 41.3 & 15.8 & 42.9 \\
8 & Lecturers had pedagogical modeling for students to follow & 44.4 & 16.7 & 38.8 \\
9 & Much time in class with practical sessions & 36.4 & 12.5 & 51.1 \\
10 & Active attitude in learning among lecturer-student & 22.8 & 52.7 & 24.6 \\
\hline
\end{tabular}

Table 6. Difficulties of student teachers in learning professional skills and internship $(\mathrm{N}=448)$

\begin{tabular}{|c|c|c|c|}
\hline No. & Difficulties & Mean (SD) & Order \\
\hline \multicolumn{4}{|c|}{ Learning professional skills at the university } \\
\hline 1 & Meet the output standards of the training program & $3.11(1.07)$ & 1 \\
\hline 2 & Acquire content of basic knowledge & $2.81(1.18)$ & 7 \\
\hline 3 & Hardly understanding lecturers' teaching methods. & $2.84(1.20)$ & 6 \\
\hline 4 & The complexity of management and evaluation from the pedagogical university & $3.04(1.22)$ & 2 \\
\hline 5 & Complex in the content of materials, textbooks & $2.98(1.22)$ & 5 \\
\hline 6 & Inappropriate in managing time for learning theory and practice & $3.04(1.17)$ & 2 \\
\hline 7 & Inadequate facilities and equipment to support learning & $2.99(1.29)$ & 4 \\
\hline \multicolumn{4}{|c|}{ Internship at high schools } \\
\hline 1 & Understand psychophysiological characteristics of students & $3.10(1.04)$ & 13 \\
\hline 2 & Design innovative lessons & $3.20(1.03)$ & 3 \\
\hline 3 & Design lessons that suit different students & $3.20(1.10)$ & 3 \\
\hline 4 & Determine right lesson objectives and identifying core knowledge of the lesson & $2.96(1.15)$ & 20 \\
\hline 5 & Develop a clear layout of the lesson & $2.90(1.18)$ & 22 \\
\hline 6 & Time managing in class & $3.18(1.18)$ & 6 \\
\hline 7 & Build a democratic, open, friendly, and cooperative learning environment & $2.97(1.28)$ & 19 \\
\hline 8 & Opening the lesson that creates excitement for students & $3.06(1.19)$ & 14 \\
\hline 9 & Using language during the teaching process & $3.05(1.17)$ & 15 \\
\hline 10 & Choosing appropriate teaching methods & $3.05(1.17)$ & 15 \\
\hline 11 & Using informative technology, facilities, and equipment at high schools & $2.90(1.26)$ & 22 \\
\hline 12 & Applying new methods in examination and evaluation & $3.11(1.27)$ & 10 \\
\hline 13 & Encourage students to learn & $3.11(1.17)$ & 10 \\
\hline 14 & Inspiring students to learn & $3.19(1.17)$ & 5 \\
\hline 15 & Organizing outside classroom activities & $3.28(1.16)$ & 1 \\
\hline 16 & Classroom work and activities for students & $3.10(1.13)$ & 12 \\
\hline 17 & Class management & $3.26(1.16)$ & 2 \\
\hline 18 & Coordinate with teachers, students' parents, and the community in educating students & $3.15(1.15)$ & 8 \\
\hline 19 & $\begin{array}{l}\text { Communicate and behave appropriately with teachers, students, and other forces in } \\
\text { the school }\end{array}$ & $3.04(1.20)$ & 17 \\
\hline 20 & Implement professional regulations at high schools & $2.87(1.26)$ & 24 \\
\hline 21 & Develop, manage and use teaching records & $2.94(1.31)$ & 21 \\
\hline 22 & Developing the subject curriculum & $3.04(1.25)$ & 17 \\
\hline 23 & Organize self-study for students & $3.16(1.18)$ & 7 \\
\hline 24 & Complete workload in the pedagogical internship & $3.14(1.26)$ & 9 \\
\hline
\end{tabular}
*** $p<0.001$

modern and updated theoretical contents (34.5\%), and in-class practical sessions (36.4\%) (Table 5).

Besides the overall evaluation of the training program, difficulties in learning professional skills at university and during the internship were investigated. The results are illustrated in Table 6. During the process of learning professional skills at university, pre-service teachers found the most problematic was to meet the outcome standards of the training program (Mean =
$3.11, \mathrm{SD}=1.07)$, followed by the complexity of management and evaluation from the university (Mean $=3.04, \mathrm{SD}=1.22)$ and the inappropriate in managing time for learning theory and practice (Mean $=3.04, \mathrm{SD}=$ 1.22). Regarding internship at high schools, the most difficult activities reported were to organize outside classroom activities (Mean $=3.28, \mathrm{SD}=1.16$ ), followed by class management (Mean $=3.26, \mathrm{SD}=1.16)$, designing innovative lessons that suits students $($ Mean $=3.20, \mathrm{SD}=$ 1.03; Mean $=3.20, \mathrm{SD}=1.10$, respectively). 


\section{DISCUSSION}

This study investigates the difference in training professional skills for pre-service teachers by considering the evaluation of the lecturers and the report from pre-service teachers at pedagogical institutes in Vietnam. Findings revealed that lecturers seemed to evaluate their teaching process better than their students thought. Pre-service teachers were facing various difficulties in developing their professional skills at the university, especially the practicality of the training program.

In terms of the effectiveness of the training program, most pre-service teachers reported that they learned about general capacities and pedagogical capacities the most. Obviously, in the teacher training program, the most critical capabilities that the university needs to train for students are teaching and pedagogical abilities. These are core content and also the essential outcomes in training future teachers' programs. However, a small percentage of pre-service teachers felt that their lecturers lacked the needed educational capacity. To tackle this problem, one might need to consider the appropriateness of the subject in the training program or the methodology and the content that the lecturers focused on when delivering this subject to pre-service teachers. In Vietnam, since educational programs shifted from the annual model to the credit model in 2006, the time allocated for each subject has led to many shortcomings. First, general subjects account for $38 \%$ of the total number of credits. In comparison, specialized ones take up only $16-18 \%$, and for pedagogical internships, this percentage is only ten out of the total 210 credits. Second, all training majors in the pedagogy have the same general curriculum. For example, all 14 high school teacher training disciplines share the same general subjects, rendering them unsuitable for some training majors (Pham, 2015).

Besides essential general and pedagogical capacities, other capacities also play a crucial role in developing competencies and qualities for a future teacher. However, some characteristics and skills were not focused on some subjects, according to learners' reports, namely the love and tolerance of students, the belief in students' ability to learn, the creation and the love of nature, hometown, and the leadership capacity. The Vietnamese education system trains people to build comprehensive skills (Vietnam Education and Training Ministry, 2019). Therefore, each value listed in this study has a vital role in the formation and development of modern people, meeting the demand for human resources in the contemporary society of Vietnam. It is hard for the teacher to train students to develop these skills if they have not learned.

Regarding professional skills content which are vital in future teacher the training curriculum, the study examined the duplication between lecturers' and their pre-service teachers' opinions. All components listed in this study are included in the training curriculum in Vietnam. It seems that lecturers believed they delivered pedagogical skills more effectively than their pre-service teachers thought (such as the belief in students' learning ability, autonomy, and adaptiveness to changes, teaching, and educational capacity). On the contrary, pre-service teachers seem to rate interpersonal skills more than lecturers rated themselves, such as leadership, cultural-social awareness, or social engagement skills. The explanation might lie in the lecturers' opinions about the priority content in the training program. They believed that it is much more essential to develop pedagogical skills than other skills. Therefore, they spent much more time teaching these skills to pre-service teachers before reaching skills (Kildan et al., 2013).

Looking at the training process, it follows different steps, including identifying objectives, developing content, selecting teaching methods, and evaluating. At each stage, there are specific requirements and criteria that teachers have to ensure. The comparison result between teachers' self-assessment and pre-service teachers will determine the differences in the views of these two subjects regarding each criterion of professional skills teaching more accurately. Therefore, we can understand more about the difference between lecturer and pedagogical students in implementing professional teaching activities. Also, the student's needs were expressed more clearly through this assessment. Cochran-Smith and Zeichner (2005) shared the same idea about the components of teaching education programs, including objectives, contents, assessment, and practicum. At all stages of the teaching process, lecturers evaluated themselves more highly than preservice teachers thought regarding how the required criteria were applied to their teaching. This difference was relatively significant, which means that lecturers overestimate their teaching progress compared to learners' comments, leading to difficulty meeting their needs in the professional-pedagogical skills training. Currently, society puts relatively high expectations on the quality of teacher training. Pedagogical students also have their criteria, expectations about the training process at the university. Therefore, the difference in perception on applying professional competency training criteria between lecturers and pre-service teachers is an issue to examine. Students' discouragement and frustration can lead them to drop out or neglect schoolwork and practice. The reason may come from the difficulty in applying for a job after graduation, teachers' low salary, and the quality of training at pedagogical schools that are inflexible, outdated, heavy in theory, and lack practice.

Pre-service teachers' general evaluation of the professional skill training programs is essential to understand which component satisfied them and needed innovation. Table 
4 shows that pre-service teachers were happy with the provided critical knowledge and the attraction, easy-tounderstand content. However, factors related to professional practice and pre-service teacher interaction remained below learners' expectations. This is substantial evidence for the training of teacher institutions and lecturers to adjust the training programs, especially the training methods.

Practicing professional skills at university and internship programs at high school are essential parts of the teacher training program. Despite knowing that this is essential to improve their professional skills, pre-service teachers still had difficulties reaching the standard outputs and applying professional skills at high schools. It can be seen from the data that pre-service teachers were not good at setting goals and lacked time management skills to reach the goals. The reason might be the limitation in enhancing soft skills for pre-service teachers, leading to difficulties in goal-setting, time management, outdoor activities operating, and class management. The amount of time for professional skills practicing was limited. A case study in Australia also concluded that the links between pre-service experience during practicum and what is learned at university need to focus on (Northcote \& Lim, 2009). In addition, in Vietnam, the time duration for the internship is concise, around five weeks, in which pre-service teachers can teach a class in just a couple of hours per week. Training students to work as real teachers was not enough to enhance their skills (Pham, 2015). During this period, the cooperation between lecturers and high school in-service teachers was quite loose, leading to inadequate support from lecturers to pre-service teachers. Nguyen and Hall (2016) identified the same difficulties in a study conducted among undergraduate pre-service teachers in central Vietnam. Also, the lessons learned from the internship were necessary for pre-service teachers, lecturers, and the university to understand the gaps in teacher training programs, methods, and practices at the university. This is also an opportunity to examine the suitability and update the teacher training curriculum with practical teaching and education activities in high schools. However, the lack of meetings between lecturers and school gives the chance to reflect and draw lessons from each internship. The same problem was found in India reported in a study by Desai (2011). This study concluded that the educational universities were not aware of the present activities at school. Thus, the lecturers were not well-prepared for pre-service teachers before they went to school to practice teaching (Desai, 2011). Another Indian study also raised the issue that the inadequate infrastructure and insufficient support from lecturers might be the reason for the inadequate infrastructure, poor library facilities, and online systems (Sharma \& Sharma, 2015). In South Africa, pre-service teachers' comments were the same. They complained that the inflexibility of their university did not help them prepare for what would happen in schools (Heeralal, 2011).

While developing professional skills for pre-service teachers, the function of lecturers in the program was critical throughout the development of the students' abilities. At every level of the teaching process, from setting goals to practicing with pre-service teachers in high schools, they utilized their implication of teaching. A requirement is for professors to provide instruction and direction. There was a statistically significant difference between the awareness of lecturers about their teaching process and the evaluation from their preservice teachers. This indicated that the lecturers' teaching process might not meet the expectations of their pre-service teachers. However, to determine whether the training program and the teaching process conducted by the lecturers impact the quality of teacher training, it will be necessary to consider students' professional capabilities in the future.

We acknowledge some limitations in this study. First, the cross-sectional design only allows us to record the opinions of lecturers and teachers training students at a specific point in time. Second, the information collected was mainly based on the participants' self-reports. Hence, there may be potential biases. Other components of professional skills training in university should be included in future studies, such as managers, school principals, or other employers. Third, although the requirements on output standards, training objectives, and core training contents are regulated by the Ministry of Education and Training. However, pedagogical universities are flexible in the choice of programs, training methods, and assessment. Therefore, future investigations should include more universities of education throughout the country.

\section{CONCLUSION}

Most standard criteria required by the Ministry of Education and Training were included in the professional skills training program. However, there was a significant difference in how each criterion was applied in teaching and training between lecturers and pre-service teachers. Students believed that the professional training program was still heavy in theory, had little time practicing time at university, and the lecturers' support to pre-service teachers was inadequate. Students had many difficulties achieving outcome standards, arranging learning schedules, and applying learned knowledge at the university during their internship program in high schools. The results of this study are evidence of the inadequacy of learners' needs in pedagogical training programs in teacher training institutions in Vietnam. Feedback from preservice teachers will become a foundation for needed adjustment in the lecturers' teaching process and training programs at educational institutions. 
Pedagogical universities need to improve their teaching plans, contents, and curriculum to maximize professional skills practice, develop soft skills, and support interaction between lecturers and learners. Fostering professional skills for lecturers at pedagogical universities through ideas exchanging, training workshops, or exchange programs affiliated with international teachers are highly recommended.

Author contributions: All authors have sufficiently contributed to the study, and agreed with the results and conclusions.

Funding: This work is funded by Enhancing Teacher Education Program - Vietnamese Ministry of Education and Training through "Enhancing teaching and learning quality of pedagogical subjects in teacher training" for Hanoi National University of Education, code HD 1.3.1e (HD 1.3.1.5).

Declaration of interest: No conflict of interest is declared by authors.

\section{REFERENCES}

Castro, J. F., Glewwe, P., \& Montero, R. (2019). Work with what you've got: Improving teachers' pedagogical skills at scale in rural Peru. Peruvian Economic Association, 121, 1-33.

Cheng, M. M. H., Cheng, A. Y. N., \& Tang, S. Y. F. (2010). Closing the gap between the theory and practice of teaching: Implications for teacher education programs in Hong Kong. Journal of Education for Teaching, 36(1), 91-104. https://doi.org/10.1080/ 02607470903462222

Clotfelter, C., Ladd, H., \& Vigdor, J. (2010). Teacher credentials and student achievement in high school: A cross-subject analysis with fixed effects. Journal of Human Resources, 45(3), 655-681. https:/ / doi.org/10.3368/jhr.45.3.655

Cochran-Smith, M. \& Zeichner, K. M. (2005). Studying teacher education: The report of the AERA Panel on Research and Teacher Education. American Educational Research Association: Lawrence Erlbaum Associates Publishers.

Darling-Hammond, L. (2006). Constructing 21st Century teacher education. Journal of Teacher Education, 57(3), 300-314. https://doi.org/10.1177/ 0022487105285962

Das, J., Dercon, S., Habyarimana, J., \& Krishman, P. (2007). Teacher shocks and student learning: Evidence from Zambia. Journal of Human Resources, 42(4), 820-862. https:// doi.org/10.3368/jhr.XLII.4. 820

Desai, A. J. (2011). Problems of teacher education in India. International Journal for Research in Education, 1(1), 54-58.

English, C. \& Bareta, L. (2005). Milestone 3: Literacy professional development project.

Guerriero, S. (2014). Teachers' pedagogical knowledge and the teaching profession: Background report and project objectives. https://www.oecd.org/education/ceri/
Background_document_to_Symposium_ITELFINAL.pdf

Hajjar, S. T. E., \& Alkhanaize, M. S. (2018). Exploring the factors that affect employee training effectiveness: A case study in Bahrain. SAGE Open - Research Paper, 8(8), 1-12. https://doi.org/10.1177/ 2158244018783033

Heeralal, P. J. (2011). Pre-service teachers' experiences of teaching practice: Case of South African University. Journal of Social Sciences, 28(2), 99-105. https://doi.org/10.1080/09718923.2011.11892933

Kiggundu, E. (2007). Teaching practice in the Greater Vall triangle area: The student teachers' experience. Journal of College Teaching and Learning, 46, 25-36. https://doi.org/10.19030/tlc.v4i6.1572

Kildan, A. O., Ibret, B. U., Pektas, M., Aydinozu, D., Incikabi, L., \& Recepoglu, E. (2013). Evaluation views of teacher trainees on teacher training process in Turkey. Australian Journal of Teacher Education, 38(2), 4. https://doi.org/10.14221/ajte. 2013v38n2.10

Korthagen, F., Loughran, J., \& Russel, T. (2006). Developing fundamental principles for teacher education programs and practices. Teaching and Teacher Education, 22, 1020-1041. https:/ / doi.org/10.1016/j.tate.2006.04.022

Nancy, L. (2007). Critical thinking dispositions as an outcome of undergraduate education. The Journal of General Education, 56(1), 17-33. https:// doi.org/10.1353/jge.2007.0011

Negassa, T. \& Engdasew, Z. (2017). The impacts and challenges of pedagogical skills improvement program at Adama Science and Technology University. International Journal of Instruction, 10(4), 19-38. https:/ / doi.org/10.12973/iji.2017.1042a

Nguyen, C. T. (2002). Training high qualified teachers in Vietnam: Challenges and policy issues. https://cice. hiroshima-u.ac.jp/wp-content/uploads /2014/03/ 4-2-16.pdf

Nguyen, K. D. (2014). Training pedagogical skills in training teacher programs in some Asian countries [Paper presentation]. Training pedagogical skills at Hanoi University of Education, Hanoi, Vietnam.

Nguyen, V. H., Nguyen, B. H., Vu, M. H., Hoang, K. H., \& Nguyen, M. N. (2020). The Vietnamese education system and teacher training: Focusing on Science Education. Asia Pacific Science Education, 6(1), 179206. https:// doi.org/10.1163/23641177-BJA10001

Northcote, M., \& Lim, C. P. (2009). The state of preservice teacher education in the Asia-Pacific region. In C. P. Lim, K. Cock, G. Lock, \& C. Brook (Eds.), Innovative practices in Pre-service teacher education: An Asia-Pacific Perspective (pp. 23-28). Sense Publishers. https:/ / doi.org/10.1163/9789087907532_003 
Pham, K. A. (2015). Training teacher curriculum in Vietnam: Some shortcomings and development directions [Paper presentation]. International Conference about Development Teacher Training Curriculum: Opportunities and Challenges, Thai Nguyen, Vietnam.

Phillips, G. E., McNaughton, S., \& MacDonald, S. (2001). Picking up the pace: Effective literacy interventions for accelerated progress over the transition into decile one schools. http://www.minedu.govt.nz/web/docu ment/ document_page.cfm?id=6444

Podolsky, A., Kini, T., \& Darling-Hammond, L. (2019). Does teaching experience increase teacher effectiveness? A review of US research. Journal of Professional Capital and Community, 4(33), 1-8. https://doi.org/10.1108/JPCC-12-2018-0032
Sharma, S., \& Sharma, P. (2015). Indian higher education system: Challenges and suggestions. Electronic Journal for Inclusive Education, 3(4), 1-4.

Singh, L., \& Shakir, M. (2019). Teacher education: Issues and Concerns in the current scenario. IJRAR International Journal of Research and Analytical Reviews, 6(2), 1082-1091.

Texler, C. J. (2018). Teacher training in America [Paper presentation]. Teacher training models for high schools in the period of international integration, Vietnam.

Thursby, P. (2018). Education and training teachers in Australia [Paper presentation]. Teacher training models for high schools in international integration, Vietnam.

Vietnam Ministry of Education and Training (2014), Resolution No. 88/2014/QH13 on the renovation of textbooks and general education textbooks.

\section{http://www.ejmste.com}

